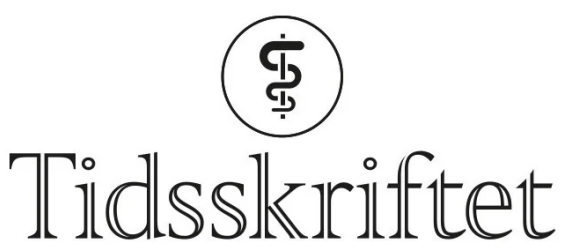

DEN NORSKE LEGEFORENING

\title{
Aluminiumsgranulomer etter barnevaksinasjon
}

KORT KASUISTIKK

\section{LINE RAVNDAL}

lineravndal@gmail.com

Hanadalen legesenter

Sandnes

Line Ravndal er spesialist i allmennmedisin og fastlege.

Forfatteren har fylt ut ICMJE-skjemaet og oppgir ingen interessekonflikter.

\section{ELISABET BERGFORS}

Seksjon for allmennmedisin

Avdeling for samfunnsmedisin og folkehelse

Göteborgs universitet

Elisabet Bergfors er ph.d., spesialist i allmennmedisin og forsker. Hun har skrevet

doktorgradsavhandling om temaet (Aspects on pertussis, pertussis vaccination and adverse events associated with aluminium adsorbed vaccines).

Forfatteren har fylt ut ICMJE-skjemaet og oppgir ingen interessekonflikter.

\section{MEHDI BEHZADI}

Avdeling for radiologi

Stavanger universitetssjukehus

Mehdi Behzadi er spesialist i radiologi og seksjonsoverlege for muskel- og skjelettradiologi.

Forfatteren har fylt ut ICMJE-skjemaet og oppgir ingen interessekonflikter.

\section{BJ $\varnothing R N$ BARSTAD}

Barne- og ungdomsklinikken Stavanger universitetssjukehus

Bjørn Barstad er ph.d., spesialist i barnesykdommer og overlege.

Forfatteren har fylt ut ICMJE-skjemaet og oppgir ingen interessekonflikter.

\section{BJARTE STEINKJER}

Hudavdelingen

Stavanger universitetssjukehus

Bjarte Steinkjer er spesialist i hud- og veneriske sykdommer, var avdelingsoverlege og er nylig pensjonert.

Forfatteren har fylt ut ICMJE-skjemaet og oppgir ingen interessekonflikter.

\section{SVEIN KJOSAVIK}

Allforsk - forskningsgruppe for allmennmedisin og samhandling Stavanger universitetssjukehus 
Subkutane vaksinasjonsgranulomer (aluminiumsgranulomer) kan forårsake langvarig kløe og er assosiert med kontaktallergi mot aluminium. Prognosen er god, men diagnosen blir ofte oversett. Vi beskriver et barn som på grunn av manglende kjennskap til diagnosen hos helsepersonell ble anbefalt utredning for malignitet.

En frisk jente på 17 måneder begynte å klø seg på en subkutan kul lateralt på venstre lår. Hun kunne klø seg til blods. Kulen var uøm og varierte i størrelse, opptil ca. 3 cm. I uker med forbigående luftveisinfeksjoner ble kløen verre og kulen større. Det tilkom etter hvert lokal hyperpigmentering, tydelig behåring og eksematøse forandringer over kulen (figur 1). Det var ingen fluktuasjon eller infeksjonstegn lokalt. Behandling med lokale steroider hadde begrenset effekt. 


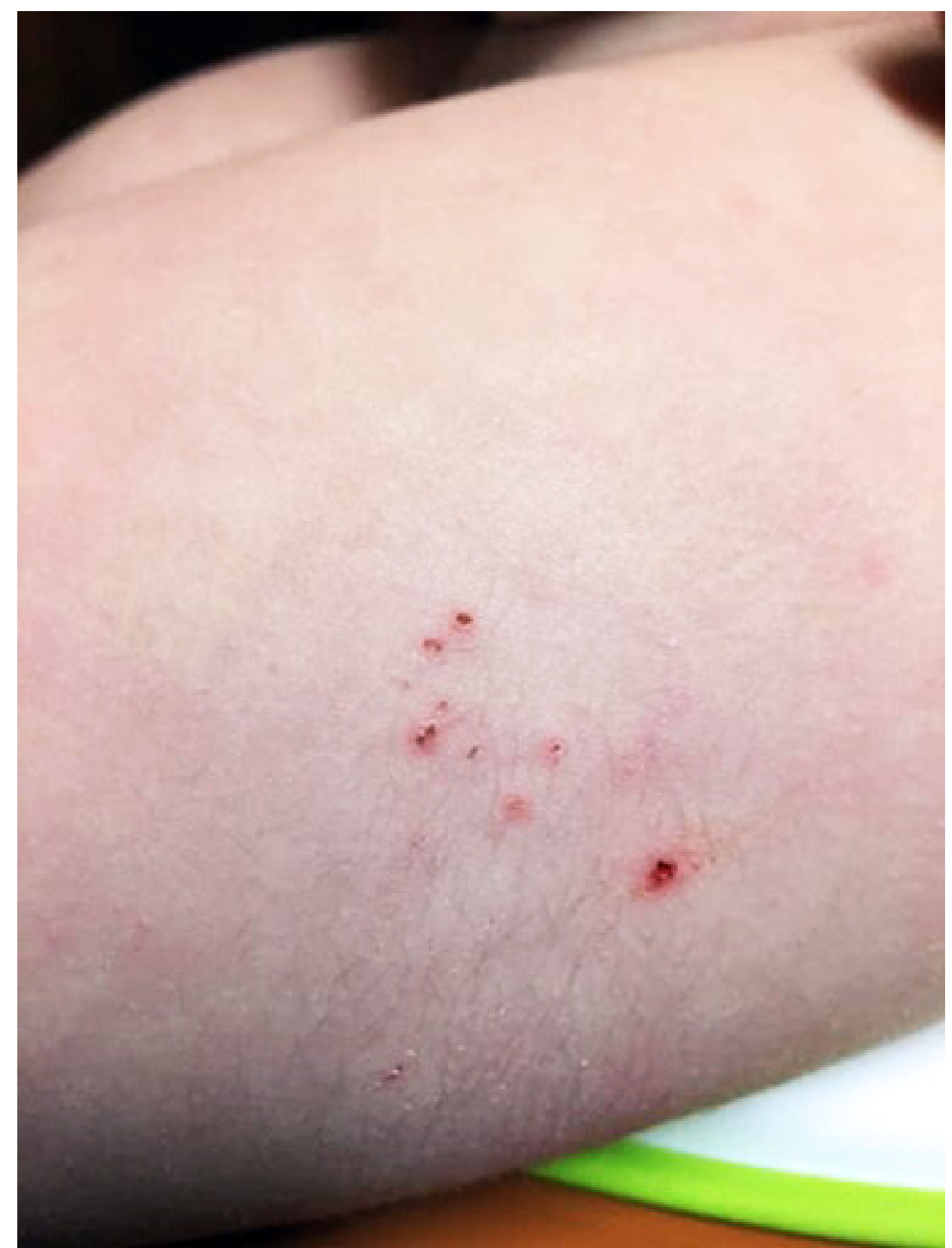

Figur 1 Pasientens laterale venstre lår med tydelig behåring og kronisk eksem.

En ultralydundersøkelse tre måneder etter at kulen ble oppdaget, viste en skarpt avgrenset, uregelmessig lobulær, multilokulær cystisk/anekkoisk lesjon (ca. $3 \times 0,5 \mathrm{~cm}$ ) i subkutant fettvev, uten affeksjon av muskelfascien. Differensialdiagnoser var organisert hematom, sekvele etter en fokal inflammatorisk prosess, vaskulær malformasjon eller annet (figur 2). Kontroller tre og ni måneder senere viste uendret lesjon. Radiologen anbefalte vurdering av barnelege. 


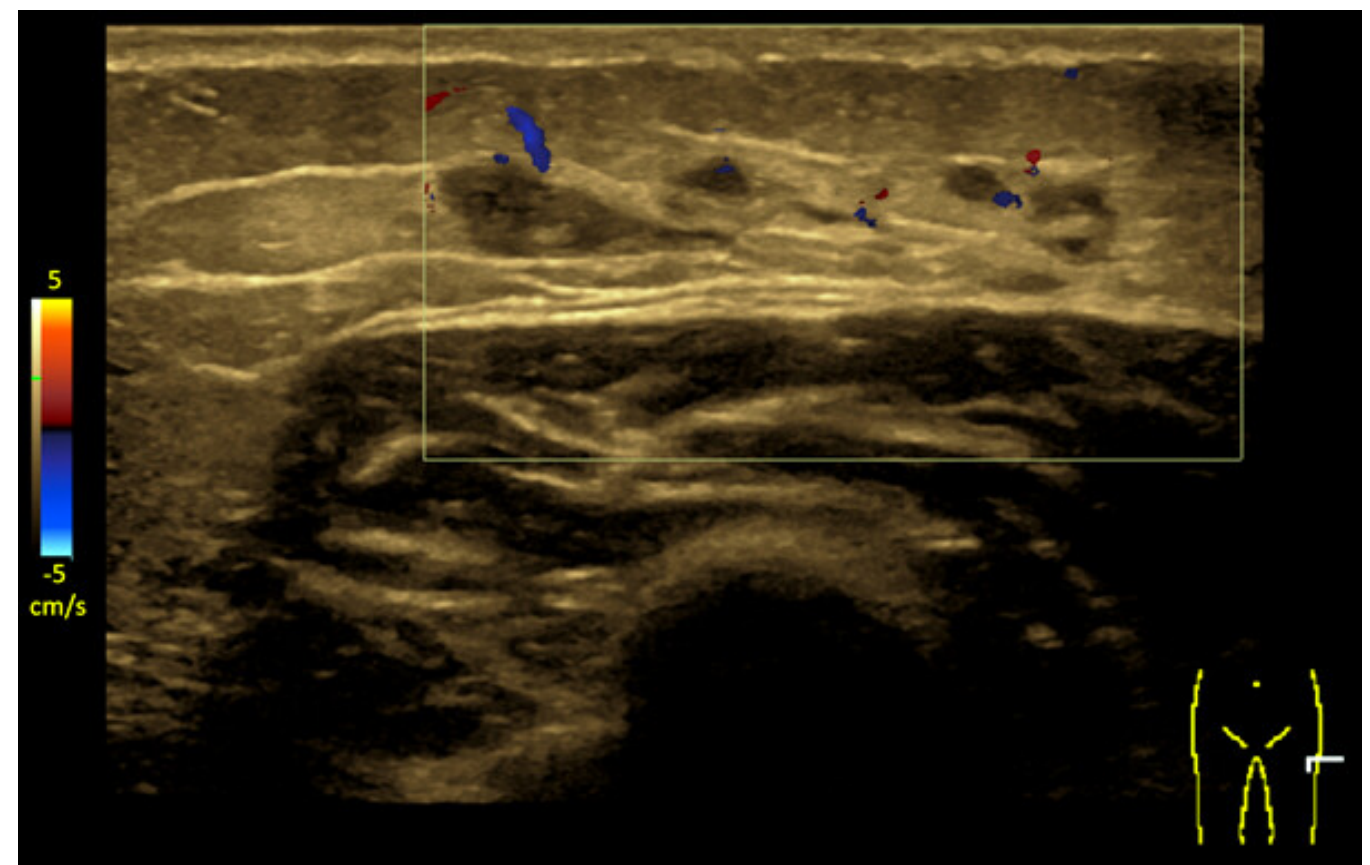

Figur 2 Ultralydbildet viser en større subkutan, tubulær hypoekkoisk lesjon uten dopplersignal.

På barneavdelingen besluttet man, på grunn av ett års varighet og uavklart årsak, å henvise jenta til MR i narkose for å utelukke malignitet. Fastlegen kontaktet helsestasjonen for å kartlegge vaksinehistorikk og injeksjonssteder. Det ble dokumentert at jenta var blitt vaksinert mot difteri, stivkrampe (tetanus), kikhoste (pertussis) og polio (DTP-IPV-vaksine) samt Haemophilus influenzae type b (Hib-vaksine) i venstre lår ved tre, fem og tolv måneders alder. Hennes symptomer debuterte altså først fem måneder etter den tredje vaksinedosen.

Det ble sendt melding om mistenkt bivirkning etter vaksinasjon til Folkehelseinstituttet, som bekreftet en sannsynlig årsakssammenheng og anbefalte fastlegen å kontakte ekspertise ved Göteborgs universitet. Legen der vurderte at anamnesen og forløpet var typisk for kløende vaksinasjonsgranulom, og foreslo epikutantest med aluminium for å komplettere utredningen. Epikutantesten ble utført på hudavdelingen da jenta var litt over tre år. Den viste sterk reaksjon ( $\left.3^{+}\right)$på aluminiumklorid-heksahydrat og $2+$ på aluminium $100 \%$. Diagnosen kløende aluminiumsgranulom ble dermed bekreftet, mer enn 1,5 år etter at jenta fikk sine første symptomer.

Klinisk ble tilstanden sakte forbedret. Etter hvert ble kulen mindre palpabel, men kløen persisterte lenger. Ved ultralyd fire år etter debut var den subkutane lesjonen forsvunnet. Fem år etter symptomdebut har jenta fortsatt intermitterende, men mindre plagsom kløe, fremdeles i forbindelse med luftveisinfeksjoner. Huden er nå normal, uten hyperpigmentering eller behåring.

Det ble aldri tatt MR av lesjonen, da malignitet syntes mindre sannsynlig etter hvert som andre undersøkelser ble gjort.

\section{Diskusjon}

Barnet hadde typisk anamnese og kliniske funn forenlig med langvarig kløende vaksinasjonsgranulom (는). Disse opptrer på injeksjonsstedet for en vaksine med aluminiumadjuvans og forekommer i alle aldre, men er absolutt vanligst i 1-2-årsalderen etter DTP-IPV- og Hib-vaksinasjonene. Frekvensen har blitt beregnet til o,63-1,18 \% av de vaksinerte i en svensk prospektiv studie (3).

Symptomene debuterer oftest lenge etter vaksineringen (måneder til år). Kløen kan være intens, og barnet kan klø seg til blods, spesielt om nettene. En eller flere faste noduli på 5$30 \mathrm{~mm}$ kan palperes subkutant der det klør. Lokalt økt hårvekst, hyperpigmentering og 
eksematøse forandringer er vanlig. I forbindelse med infeksjoner blir kløen ofte verre og noduli større. Symptomene kan vare lenge, men avtar over tid, gjerne med lengre perioder uten kløe. Kontaktallergi mot aluminium kunne påvises hos 77-95\% av barn med aluminiumsgranulomer som ble epikutantestet $(\underline{1}, 3)$. Aluminiumallergien er en langsom type-4-reaksjon, en forsinket immunreaksjon, og gir dermed ingen $\emptyset \mathrm{kt} \mathrm{risiko} \mathrm{for} \mathrm{en}$ anafylaktisk (type 1) reaksjon ved senere vaksinasjoner (4).

Har barnet en typisk anamnese og symptombilde for kløende vaksinasjonsgranulom og det kan dokumenteres at en eller flere aluminiumholdige vaksineinjeksjoner er satt i området, er det nok for å stille diagnosen. En positiv epikutantest på aluminium bekrefter diagnosen (men en negativ test utelukker den ikke). Kløen kan lindres med lokale steroider eller ved å dekke det kløende området med en hydrokolloidbandasje, men det finnes ingen kausal behandling. Aktuelle barn trenger ikke å unngå aluminiumholdige vaksiner, men om man venter til symptomene har gått i regress, reduseres risikoen for nye granulomer (11). Allergien kan gi kontakteksem blant annet ved bruk av aluminiumholdige deodoranter og hudkremer. Nye studier har vist at allergien hos de fleste ikke lenger kan påvises etter 510 år (5).

Kløende vaksinasjonsgranulomer blir ofte oversett fordi intervallet mellom vaksine og symptomdebut er langt, og fordi helsepersonell mangler kjennskap til diagnosen. Dette kan føre til bekymringer hos foreldre og unødvendige utredninger for barnet (므). I tillegg kan det gi økt skepsis til vaksiner dersom kunnskap om relativt vanlige bivirkninger mangler. Det er derfor viktig at tilstanden blir kjent blant allmennleger, barneleger, hudleger, radiologer og ansatte ved helsestasjoner. I tillegg må det være rutiner for skriftlig dokumentasjon av injeksjonssteder ved barnevaksinasjon.

Pasientens foresatte har gitt samtykke til at artikkelen blir publisert.

Artikkelen er fagfellevurdert.

\section{REFERENCES}

1. Bergfors E, Trollfors B. Sixty-four children with persistent itching nodules and contact allergy to aluminium after vaccination with aluminium-adsorbed vaccines-prognosis and outcome after booster vaccination. Eur J Pediatr 2013; 172: 171-7. [PubMed][CrossRef]

2. Salik E, Løvik I, Andersen KE et al. Persistent skin reactions and aluminium hypersensitivity induced by childhood vaccines. Acta Derm Venereol 2016; 96: 967-71. [PubMed][CrossRef]

3. Bergfors E, Hermansson G, Nyström Kronander U et al. How common are long-lasting, intensely itching vaccination granulomas and contact allergy to aluminium induced by currently used pediatric vaccines? A prospective cohort study. Eur J Pediatr 2014; 173: 1297-307. [PubMed][CrossRef]

4. Rustemeyer T, van Hoogstraten IMW, von Blomberg BME. R.J. S. Mechanisms of Allergic Contact Dermatitis p 153, 168. In: John S., Johansen J., Rustemeyer T., Elsner P., H. M, editors. Kanerva's Occupational Dermatology: Cham: Springer International Publishing; 2020.

5. Gente Lidholm A, Bergfors E, Inerot A et al. Unexpected loss of contact allergy to aluminium induced by vaccine. Contact Dermat 2013; 68: 286-92. [PubMed][CrossRef]

6. Kelly E, Leahy R, McDermott M et al. Persistent pruritic subcutaneous nodules at injection sites and other delayed type hypersensitivity reactions to aluminium adsorbed vaccines in Irish children: A case series. Acta Paediatr 2020; 109: 2692-3. [PubMed][CrossRef]

Publisert: 24. februar 2022. Tidsskr Nor Legeforen. DOI: 10.4045/tidsskr.21.0398

Mottatt 10.5.2021, første revisjon innsendt 2.9.2021, godkjent 16.1.2022.

Publisert under åpen tilgang CC BY-ND. Lastet ned fra tidsskriftet.no 26. april 2023. 